\title{
Indigenous Religion's Strategy in Maintaining their Belief
}

\author{
Iwan Setiawan ${ }^{*}$, Irfan Goffary ${ }^{2}$, Mohamad Hamim ${ }^{3}$ \\ 1 Institut Agama Islam Darussalam (IAID) Ciamis \\ 2STAI Al-Falah, Cicalengka Bandung \\ ${ }^{3}$ Sekolah Tinggi Agaman Islam Tasikmalaya \\ * Corresponding author E-mail: iwansetiawan@iaid.ac.id
}

\begin{abstract}
The purpose of this study is to discuss the patterns of strategy adherents of the Madrais or the Djawa Sunda Religion (ADS) in Cigugur, Indonesia, in maintaining their trust. This study uses a qualitative approach to the descriptive-analytic method through literature studies. Data obtained through the review of the literature and then analyzed using content analysis (content analysis) using Miles and Crow's theory of "organizational strategy." The results showed that the pattern of the strategy of adherents of the teachings of Madrais in maintaining its beliefs seen in several ways, namely: the model of prospectors, defenders, analyzers, and reactors. The prospector pattern means forming a new form of organization. The model of defenders means to survive for the stability of the organization's existence. Pattern analyzers mean dealing with internal consolidation to find an organization's safe position. Finally, the pattern of reactors is forced to succumb because of external threats and pressures and is unable to fight them.
\end{abstract}

Keywords: Indigenous Religion, Strategy, Madrais, The Religion of Djawa Sunda

\section{INTRODUCTION}

In Indonesia, many indigenous religions continue to struggle to maintain their existence in the face of government pressure. One that is in West Java is the adherents of the Madrais (formerly the Javanese Djawa Religion) whose center is in Cigugur Kuningan. Madrais teachings were spreading in several regions in West Java, such as Ciamis, Tasikmalaya, Garut, Cirendeu, Sukabumi, Bogor, and others. To face the pressures of the state, the seekers continually try in various ways to maintain their existence. These efforts can be part of a strategy to achieve the goal that still exists and may also be an adaptive response to external threats.

One of the efforts undertaken by advocates against the government is to submita judicial review of article 61 paragraph 1 and article 64 paragraph 1 of the 2013 Administrative and Population Act (Adminduk), revision of the 2006 Act. The result is November 2017, the second decade of Court reform The Constitution(MK) granted the judicial review of ancestral religious beliefs on article 61 paragraph 1 and article 64 paragraph 1 of the 2013 Administrative and Population Act (Adminduk), a revision of the 2006 Act. The MK decision requires the Indonesian government to add choicesto the religious column on identity cards (KTP), which is the "flow of trust" for followers (Mubarok, 2019). In addition to effortsmade to the government of the Djawa Sunda Religion community, they al so sought to develop strategies to maintain their beliefs.

Rangkuti definesstrategy as a tool to achievegoals and, according to Argyris, quoted Rangkuti, the procedure is a continuous response or adaptation to external threats with internal strengths and weaknesses of the organization that affect the organization (Rangkuti, 1997). The strategy developed by the followers of the Madrais teachings is a response to the upsand downs of the state's recognition of their lessons as well as to other native religions in Indonesia. Samsul Maa'rif clearly explained the ups and

* Copyright (c) 2020 Iwan Setiawan et.all

This work is licensed under a Creative Commons Attribution-ShareAlike 4.0 International License. 
International Journal of Islamic Khazanah, Vol. 10 No. 2: 61-68

Indigenous Religion's Strategy in Maintaining their Belief

Iwan Setiawan, Irfan Goffary, Mohamad Hamim

downs of government recognition of ancestral religion in Indonesia from time to time. Ma'arif began by explaining that in the Old Order era, faith is defined very exclusively, which hada holy book, a prophet, and international recognition. This definition determines who is served and who is not served. The Old Order government to oversee the flow of trust, formed the Trust Flow Monitor (PAKEM) in 1953.

During the transition to the new order precisely in 1965 (when there waspolitical upheaval) was born Presidential Decree (which later became PNPS Law 1/1965 on Blasphemy). This presidential decree wants to protect the official religion from blasphemyby a stream of faith. In the same year, the flow of trust under enormous pressure, especially after the events of 30 September 1965 (G/30/S/PKI), they were suspected of being part of communism. A critical moment for the flow of trust occurred in 1978. This year the MPR Decree came out stating that belief is not a religion but culture. TAP MPR No. 4 of 1978 also requires the presence of a religious column (the column must be filled with one of the five religions) in the civil registration form (Damami, 2011). Nowadays, the religious column is listed on the identity card (KTP). According to Ma'arif, in the second period of the New Order, beginning in 1978, religion began to 'be formalized' (Maarif,2017).

In the post-reform era, with the inclusion of human rights clauses in state legal instruments, adherents of the faith again received recognition. With human rights instruments, followers of the trust are protected from being forced to convert to "official" religion. But discrimination still exists, with Article 61 of the 2006 Adminduk Law: the identity of belief is not recorded in the religion column. With such regulations, according to Ma'arif, the state has perpetuated 'the politics of recognition.' The political purpose of recognition is thatreligion is used to distinguish citizens (Maarif, 2017).

The ups and downs of recognition of indigenous religion by the state, as explained by Samsul Ma'arif, made the followers of local religions devise strategies or strategies to maintain their religious existence. So this paper, in general, the first part describes the adherents of Madrais teachings covering history, theology, rituals, and current issues. Part two explains the patterns of strategies of followers of local religions (indigenous religion) in maintaining their religious system in the midst of the 'onslaught' of religious politics by the state experienced by believers. In thisresearch, Mileand CrowTheory is applied to analyze the pattern of survival strategies. The theories used regarding organizational strategy include innovative and creative strategies that metamorphose into several designs, namely: prospectors, defenders, analysts, and reactors. The prospector pattern means forming a new form of organization. The model of defenders means to survive for the stability of the organization's existence. Pattern analyzers mean dealing with internal consolidation to find an organization's safe position. Finally, the pattern of reactorsis forced to succumb because of external threats and pressures and isunable to fight them.

\section{METHODOLOGY}

This study uses a qualitative approach with descriptive-analytic methods through literature studies. Data obtained from the review of the literature and then analyzed by content analysis (content analysis). The primary data used in this study are books and journal articles about the followers of the Javanese religion of Sundanese (ADS) and books on organizational strategy in maintaining its existence, namely Miles and Crow's book titled Organizational Strategy, Structure, and Process published by Stanford University Press. The secondary data are books and journal articles about the religion of Javanese Sundanese(ADS). 


\section{RESULTS AND DISCUSSION}

\section{Agama Djawa Sunda (ADS)}

The Agama Djawa Sunda was founded by Kyai Madrais or Pangeran Sadewa Alibasa Kusumawijayaningrat. He is a descendant of the Sultanate of Gebang Cirebon. According to Didi Wiardi, Kyai Madrais felt dissatisfied with the religion of Islam that did not place his status as befits others, both in the life of this world and the hereafter. Kyai Madrais was hurt because he was accused of being a 'bastard' by Kyai, who taught him at the Islamic boarding school because he was PrinceGebang's daughter from a concubine. At that time, a concubine - by Kyai, his teacher Madrais and public opinion - was interpreted as an informal wife, and the child of a concubine was considered an illegitimate child. In addition, according to the Kyai, illegitimate children will notbe accepted in heaven. Thus, Kyai Madrais feltdisappointed with the incidentand considered the teachings of Islam not to protecthim. Therefore, Madrais left the Pesantren to seek truth and justice. After studying to a number of Islamic boarding schools, Madrais taught Islam, which was mixed with adat or vice versa with religion (Wiardi,2007).

Around 1925 the teachings of Kiai Madrais by the people were called Agama Djawa Pasoendan or Agama Djawa Soenda abbreviated as ADS. According to Didi Wiardi, the naming of Jawa and Sunda did not rule out the possibility because the essential elements of the belief contained in it took a lot from the cultural aspects of Djawa (Cirebon) and Sundanese. Probablyalso because its adherents wereSundanese and Javanese Cirebon (Waluyajati, 2017).

After Madrais died (in 1939; aged 117 years), Cigugur'sleadership was continued by hisson Prince Tedjabuana Alibasa, until (at the government's recommendation) Prince Tedjabuana dissolved the ADS through Government Decree No. SK. 001 / KPTS / DK 1964 (Syukur, 2011). In 1981, Prince Djatikusumah (the son of Pangeran Tedjabuana), together with ADS followers, created the organization of the Karuhun Urang Customary Community (PACKU). Like ADS, the PACKU organization was also banned by the government through the decision of the West Java High Prosecutor's Office dated August 25, 1982, with Decree No. 44 of 1982. Furthermore, after the reform period, due to freed om of belief, Prince Djatikusumah (son of Prince Tejabuana) reunited Madrais followers and call themselves as AKUR Citizens (Adat Karuhun Urang) until now (Dagun \& Purwanto, 2000).

\section{Theology of Agama Djawa Soenda (ADS)}

The Cigugur viewer holds that all life and life originate from Gusti Sikang sawiji-wiji (God, who is the essence of all essence) or Gusti Nu MahaTunggal (God Almighty). He is the one, butno one is holding it. There is no direction and no place, there is Himself, and his power is no match. The book that is used by the Cigugur readers is a book written by the book. This means thatall aspects of the physical-spiritual life of humansand the universe are read as a holy book. Even so, they did not rule out the possibility of them also reading writings called writing scribes, which were written in various teachings(Mutaqin, 2013).

The teachings of Madrais up to now have been passed down to residents through (1) piwulang, pitutur (advice); (2) calling, pepeling (warning); (3) tarekah (symbolic activities) carried outin traditional ceremonies. The teachings or guidance for adherents of the teachings of Madrais contained in "pikukuh tilu",which are 3 things that must be held firmly as a foundation of life to achieve "sampurnaning inhaled, death sajatining" and "sampurnaning hurip, sajatining starch" (perfection of life). The contents of the pikukuh tilu are ngaji badan, tuhu/mituhu kana tanah, and madep ka ratu-raja 3-2-4-5lilima 6. Ngaji badan is related to if you want to live safely, you must know God, before you know God, you must know yourself first (Suhaenah etal., 2017). Humans must know sasaka rupa (self-form) and the sakarupa (pure form) of 
International Journal of Islamic Khazanah, Vol. 10 No. 2: 61-68

Indigenous Religion's Strategy in Maintaining their Belief

Iwan Setiawan, Irfan Goffary, Mohamad Hamim

oneself. Mikukuh kana tanah means obeying God-given destiny for land (place). There are two kinds of property, i.e.; tanah amparan (homeland) and tanah adegan (physical and spiritual human beings). Madep ka-raja is an essential aspect of a belief or confidence in the nature given by God. Ratu Raja consists of six groups namely ratu raja tilu 3 means serving the three elements in person (sir, taste, thought / determination, speech, behavior), ratu-raja 2 (pairing nature), ratu-raja 4 (two hands and two legs activity), ratu-raja 5 (the five senses), ratu-raja lilima (awareness of the existence of five nations in the world as God's destiny), ratu-raja 6 (complete and perfect unity of the various elements of human life and the universe) (Dagun \& Purwanto, 2000).

\section{Rituals}

Pikukuh tilu described above is transformed into a routine of worship called determination if the feeling, which is to arrange the taste so that itcan incarnate in common behavior patterns. The following is a method of resolution of flavor that is commonly practiced by adherents of Madrais. Determination of feeling done in a sitting position like a person who is meditating and is usually done in two ways, namely; how to taste for yourself and how to taste donetogether (Setiawan, 2013).

In 1940, children of ADS adherents from Cigugur who studied in Kuningan often used to be mocked with the words" Madrais pupil, sleeper, Paehna ge ditambelaan, Teu disarunatan" (murid Madrais, likes to heat the body in the fireplace, use a coffin whenever he or her die, no one is circumcised). One of the Madrais rituals is often a ritual of "worshiping" fire in front of hawu (furnace). Even in the places of Kiai Madrais'swandering, often ngadapur (make a furnace). So some people consider the adherents of Madrais to worship fire. Furthermore, if someone dies, they must use a coffin made of teak wood following the philosophy of Sunda mulih ka jati mulang ka asal. Moreover, the teachings of Madrais teach that men do not need to be circumcised, because it means violating God's nature, namely discarding what God has given. Throwing it means not being thankful for what God has given.

In addition to the above rituals, traditional rituals that are still carried out up to now are seren taun traditional ceremonies. The seren taun ritual is a traditional ceremony of a Sundanese agrarian society that combinesvarious Sundanese arts and cultures (angklung buncis, rengkong, dog dog lonjor, dadung party, buyung dance, tarawangsa, ronggeng gunung, gamelan "si Monggang," and others) and combined with ritual processions of indigenous peoples that have profound meanings. This celebration is carried out every year precisely on the 22nd of Rayagung in the Sunda calendar. Every year, thousands of peoplefrom all over West Java usually come to Cigugur to attend the event, generally adherents of Madrais teachings (Indrawardhana, 2012).

\section{ADS Adherents Strategies in Maintaining Their Trust}

Based on thehistorical description of the Djawa Sunda Religion or Sundanese Wiwitan religion that developed in Cigugur, this section will explain the ADS strategy in maintaining their religious system. According to Miles and Snow, "The organization must continuously modify and improve the mechanism to achieve its objectives, by rearranging the structure of roles and relationships and the decision making process and its control" (Abdalla \& Altaf, 2018)(Miles et al., 2003). Furthermore, Miles and Snow categorize organizational strategies into four categories: defenders, prospectors, analyzers, and reactors. Each has a type of procedure in responding to its environment, configuration of different structures and processes.

Defender types are organizations that emphasize the use of organizational stability and survival strategies. The organization maintains its core organization without making any changes. This type of 
International Journal of Islamic Khazanah, Vol. 10 No. 2: 61-68

Indigenous Religion's Strategy in Maintaining their Belief

Iwan Setiawan, Irfan Goffary, Mohamad Hamim

prospector is almostalways looking for opportunities and still experimenting with external responses to the organization. This type of organization uses a strategy that prioritizes innovation and creativity to create new products. Types of analyzers are organizations that use strategies between defenders and prospectors. This means that this organization is not too brave to take significant risks in innovation but still trying to create excellencein service to its members. Types of reactors are types of organizations that do not have a specificapproach in dealing with external pressures. Thistype of organization only tries to react to changes thatoccur outside the organization (Miles et al., 2003). The Miles and Snow categorization will be used to analyzethe strategiesa dopted by ADS adherents in maintaining their religion.

1. Establishment of the Trimulya Education Foundation in 1958.

Based on the Miles and Snow category, ADS entered the prospector category because it tried to be creative and innovate by establishing the Trimulya Foundation in order to educate the next generation of teachings through Tri Mulya Middle School and SMK Daya Mandiri. Tri Mulya Middle School used to be very popular in the Kuningan area, and although there are not so manystudentsnow, because of the many choices of other educational places, it still runs with a load of loving attitudes towards local values. To continue at the senior secondary level, SMK Daya Mandiri was also established to accommodate the children of residents.

2. Affiliated with BKKI Between 1956 and 1964 (dissolution).

The results of the 1955 elections showed that the abangan group won political battles, including the mysticism (Maarif, 2017). Then it facilitates the political moment for the mysticism group. Immediately after the election, precisely on 19-21 December 1955, the mysticism group held its first National Congress in Semarang. Six hundred eighty representatives from 70 organizations attended the congress. At the congress, they formed the Badan Kongres Kebatinan Indonesia (BKKI) and elected Mr. Wongsonegoro as chairman.Since this congress, thegroup of beliefs is known as the "mysticism". The teachings of Madrais Cigugur since 1956 are registered as members of the BKKI even in West Java there are 22 schools of mysticism which are also registered as members of the BKKI. The purpose of BKKI is, of course, fighting for the recognition of the government, which has an impact on government services to all mysticism groups in Indonesia. In 1960, the existence of the BKKI received opposition from the Islamic Youth Congress, which emphasized its rejection of mysticism (Maarif,2017).

3. $\quad$ "Recapture" the palace that was previously handed over to the Catholics (1978). After ADS disbanded in 1964, the building of the former ADS activities by Prince Tejabuana was handed over to the Cigugur people who were former members and subsequently used as a place for Church Masses. A fewyears later, in connection with the tourism development plan on October 7, 1976, the Kuningan district government asked Prince Tejabuana the former ADS building to become a Museum. Prince Tejabuana, through his son Prince Jatikusumah, allowed it on the grounds that it would preserve the cultural heritage of the nation in the field of history and archeology in order to foster national awareness. The 'seizure' of the palace could be part of a strategy to revive the teachings of Madraisas evidenced the followingyear (1981), Prince Jatikusumah founded PACKU (Paguyuban Adat Cara Karuhun Urang).

4. The implementation of the Seren Tahun event, although it has been banned since 1982 (for almost 17 years) and allowed to return in 1999, is a real effort by ADS residents to maintain the rituals typical of Madrais. After being banned by government regulations twice (in 1964 and 1982). Nutu ceremony (the forerunner of the seren taun ceremony) which is usually held every year, then carried out by distributing rice to each resident to be peeled one by one. After it is finished, it is collected at Paseban, where a simple ceremony is held. The annual Nutu traditional ceremony can 
International Journal of Islamic Khazanah, Vol. 10 No. 2: 61-68

Indigenous Religion's Strategy in Maintaining their Belief

Iwan Setiawan, Irfan Goffary, Mohamad Hamim

only be held again on a large scale by the indigenous people of Cigugur starting in 1999, named after the collapse of the New Order (1997). Cigugurindigenous people are able to rise up and actualize themselves in the midst of society. The impact of the Kuningan regional government considers that traditional and religious activities in Cigugur are a cultural asset, even the archipelago that can be developed (Wiardi, 2007).

5. The activity of compiling the teachings of Madrais by Prince Jatikusumah is an effort in order to maintain the instructions of Madrais so that it is better understood by his followers. Prince Jatikusumah was given the title of Rama Panyusun because he composed the teachings of Madrais, which had not yet been produced. Prince Jatikusumah compiled the books "Breaking Papakon Pikukuh Tilu" and "Surasa Husus." The first is in the form of poetry (poetry), and the second is in the way of fluent language (prose)(Syukur, 2011). Kyai Madrais himself is called Rama Panyipta (Father of Creation) because he is considered the creator of teachings. At the time of Kyai Madrais, there were teachings that were still not understood by the residents, because they were full of symbols (siloka) and signs, but the residents carried out all their orders becausethey felt sure and believed. The prince of Tejabuana was given the title Rama Pangwedar because he explained the teachings of Madrais, which were difficultto understand.

6. Establishing PACKU as an incarnation of ADS in 1981 and changing again to AKUR after reforms could be a strategy for adherents of ADS to perpetuate their existence with new'clothes.' PACKU is even intended to accommodate followers of ADS who were previously converted to Catholicism. The reason for the dissolution of PACKU is that the governmentsniffed that this organization was an incarnation of the previous ADS, so in 1982, the government banned the PACKU organization including the prohibition of procuring seren taun ceremonies through the West Java High Prosecutor's Office dated August25, 1982, known as SK. No. 44 of 1982.

7. After about 15 years, the implementation of Madrais was carried out clandestinely. After the collapse of the new order of religious life, the followers get a fresh breeze by accommodating international human rights clauses. So after the reformation, Prince Djatikusuma reunited followers of Madraisand called themselves AKUR Citizens (Adat Karuhun Urang) until now (Wiardi, 2007).

8. To maintain the teachings of Madrais, the ADS Leaders registered them selves to beregistered with the Director-General of Trustworthiness Development(BHK) under the Ministry of Education and Culture. As a result, in 1982, Madrais's teachings were registered with the Director-General of Trustworthy Development. BHK is one of the Director Generals in the Ministry of Education and Culture, which wasformed on February5, 1979. In 1980, the BHKDirectorate changed itsnameto PPK (Pembinaan Penghayat Kepercayaan Kepada Tuhan Yang Maha Esa). The Directorate is tasked with documenting and registering Trust groups, especially those that have been collected by HPK (Himpunan Penghayat Kepercayaan Kepada Tuhan Yang Maha Esa), which was an independent organization of the ceremonies at the time (Wiardi, 2007).

9. In 2000, together with other indigenous peoples, established AMAN in the context of consolidating and advocating for the rights of indigenous peoples regarding ulayat land and others. Aliansi Masyarakat Adat Nusantara (AMAN) is an independentsocial organization with a vision to createa just and prosperous life for all Indigenous Peoples in Indonesia. AMAN worksat the local, national, and international levels to represent and advocate for Indigenous Peoples's issues. AMAN has2,304 indigenous communities throughout Indonesia, which number around 17 million individual members. Indigenous Peoples have sovereignty over land and natural resources, socio-cultural life 
International Journal of Islamic Khazanah, Vol. 10 No. 2: 61-68

Indigenous Religion's Strategy in Maintaining their Belief

Iwan Setiawan, Irfan Goffary, Mohamad Hamim

governed by customary law, and conventional institutions that maintain the sustainability of their lives as indigenouscommunities.

AMAN was formed in 1999 in accordance with the decision of the first Archipelago Indigenous Peoples Congress (KMAN I). On March 17, 1999, more than 400 Indigenous leaders in the archipelago gathered at the Hotel Indonesia in Jakarta. KMAN I discuss and seek solutions to overcome threats to the existence of Indigenous Peoples, including violations of human rights, expropriation of customary lands, cultural harassment, and various policies that discriminate against Masyarakat Adat. As a traditional leader, Pangeran Jatikusumah, was one of AMAN's chairmen and was also a representative of traditional leaders from Indonesia in international meetings, namely The Founding Meeting of the World Council of Religion Leaders held at The United Nations Conference Center in Bangkok, Thailand on 13 to June 14, 2002.

10. Involvement of Madrais teachings in NGOs / NGOs concerned with advocating adherents of native Indonesian religions such as Dewi Kanti (one of Prince Jatikusumah's daughters) joined ICRP and ANBTI (National Unity in Diversity Alliance). ICRP (Indonesian Con ference on Religion and Peace) is a non-sectarian, non-profit, non-governmental, and independent legal entity foundation organization engaged in the field of interfaith and dialogue of religions. Served by his birth by interfaith leadersincluding Gus Dur, Johan Efendi, and others, ICRPseeks to spread the tradition of dialogue in the development of a humanist and plural istreligious life in the country.

ICRP cooperates with religious and interfaith institutions as well as individuals as part of the development of interreligious dialogue and beliefs and the spirit of appreciation for the reality of differences in beliefs in society. In addition, the ICRP is also actively networking with institutions concerned about fighting for pluralism and peace to fight injustice in the social system, gender, human rights, etc. (http://icrp-online.com/profil/).

\section{CONCLUSION}

To respond to the ups and downs of state recognition of adherents of indigenous religions. Followers of belief in God Almighty endeavor in various ways to defend the teachings of their ancestors. No exception, followers of the Djawa Sunda Religion in Kuningan Cigugur. They seek to build innovative and creative strategies that morph into new forms (prospectors), defend for the stability of the existence of the organization (defenders), deal with internal consolidation ways to find the organization's safe position (analyzers), or are forced to succumb because of external threats or pressures and no power to fight it (reactors). From some of the efforts described earlier, it can be analyzed that adherents of Madrais can be categorized as organizations with prospectorsand defenders. Although in some partsalso included types of analyzers and reactors. The affiliation of ADS / PACKU / AKUR with government and nongovernment organizations (BKKI, Director General of BHK, AMAN, ICRP, ANBTI) proves that those who adhere to the teachings of Madrais are categorized as defenders, meaning to survive by joining other organizations for organizational stability. Besides organizing the ceren seren taun ceremony, which is intended to maintain the existence of the organization, it also includes the category of defenders. Asfor the establishment of the Tri Mulya Foundation, the change in the name of the organization from ADS to PACKU then became AKUR, and the "struggle" of Paseban from Catholicism, in thiscase, entered the prospector's type because they dared to make new and innovative and creative breakthroughs and changes. The activity of rearranging Madrais' teachings by Prince Jatikusumah is in the category of analyzers, which means trying to internally consolidate the organization by strengthening the foundations of the learning so that it is easier for followers to understand. Included in this category are also sending officers from 
Cigugur in marriages performed by followers in areas such as Ciamis, Banjar, Tasikmalaya, Garut, and Cireundeu. The type of reactors can be seen in the case of the dissolution of ADS in 1964, the ban of PACKU in 1982 , and the ban on the celebration of serenum for about 17 years. Although the ceremony of seren taun is carried out clandestinely.

\section{REFERENCES}

Abdalla, M. M., \& Altaf, J. G. (2018). Análise Crítica do Discurso em Administração/Gestão: sistematização de umframework metodológico para o modelo tridimensional de Norman Fairclough. Encontro de Ensino e Pesquisa Da Anpad, At Porto Alegre.

Dagun, S., \& Purwanto, A. (2000). Adat Karuhun Urang: Pemaparan Budaya Spiritual. Lembaga Pengkajian Kebudayaan Nusantara.

Damami, M. (2011). Kepercayaan Terhadap Tuhan Yang Maha Esa Pada Periode 1973-1983: Sebuah Sumbangan Pemahaman tentang Proses Legalisasi Konstitusional dalam konteks Pluralitas Keberagamaan di Indonesia. Kementerian Agama RI.

Indrawardhana, I. (2012). Jejak Sejarah Kiai Madrais (Pangeran Sadewa Alibasa Kusuma Wijayaningrat). Maarif, S. (2017). Pasang Surut Politik Rekognisi Agama Leluhur dalam Politik Agama di Indonesia (L. Khairiyah Pary (ed.)). CRCS (Center for Religious and Cross-cultural Studies).

Miles, R. E., Snow, C. C., Meyer, A. D., \& Coleman, H. J. (2003). Organizational Strategy, Structure, and Process. Stanford Business Books. https://doi.org/10.2307/257544

Mubarok, H. (2019). History of Advocasy of Religious Pluralism: Case Study of Ancestral Religion Advocasy in Indonesia. Dialog: Jurnal Penelitian Dan Kajian Keagamaan, 42(2), 134-145. https://jurnaldial og.kem enag.go.id/index.ph p/dialog/article/view/329

Mutaqin, A. (2013). Spiritualitas Agama Lokal (Studi Ajaran Sunda Wiwitan aliran Madrais di Cigugur Kuningan Jawabarat). Al-Adyan: Jurnal Studi Lintas Agama, 8(1), 89-102. https://doi.org/https://doi.org/10.24042/ajsla.v8i1.528

Setiawan, I. (2013). Menembus Batas-Batas Agama: Konstruksi Damai di Susuru [Universitas Gadjah Mada]. http://etd.repository.ugm.ac.id/home/detail_penc arian/63387

Suhaenah, E., Rohaeni, A. J., \& Listiani, W. (2017). Rekontruksi pikukuh Tilu dalam Manajemen Babarit pada Upacara Serentaun Cigugur Kuningan. Panggung: Jurnal Seni Budaya, 27(2), 168-176. https://doi.org/http://dx.doi.org/10.26742/panggung.v27i2.258

Syukur, A. (2011). Islam, Etnisitas, dan Politik Identitas: Kasus Sunda. MIQOT: Jurnal Ilmu-Ilmu $\begin{array}{llll}\text { Keislaman, } \quad X X X V(N o .2 & \text { Juli-Desember }\end{array}$ https://doi.org/https://doi.org/10.30821/miqot.v35i 2.15

Waluyajati, R. S. R. (2017). Agama Djawa Sunda (ADS). Religious:Jurnal Studi Agama-Agama Dan Lintas Budaya, 1, 103-109. https://doi.org/https://doi.org/10.15575/rjsalb.v1i2.1389

Wiardi, Di. (2007). Bertahan Untuk Tidak Gugur, Religi (Adat) Cigugur. In Sisi Senyap Politik Bising. Kanisius. 